\title{
VARIABLES CONTRIBUTING TO FARMERS' ATTITUDE TOWARDS IPM PRACTICES IN RICE CULTIVATION IN GODAGARI, RAJSHAHI
}

\author{
M. Mostafizur Rahman \\ Department of Agronomy and Agricultural Extension, University of Rajshahi, \\ Rajshahi 6205, Bangladesh. \\ Email: mostafizur2001@yahoo.com
}

\begin{abstract}
To identify the factors contributing to the farmers' attitude towards Integrated Pest Management (IPM) practices in rice cultivation, 158 family heads of the Farmers Field Schools (FFSs) at Godagari Upzila under Rajshahi District were chosen at random to constitute the subjects of the study. Data were collected from 5 September, 2006 to 28 January, 2007. Twenty four selected characteristics of the farmers were considered as the independent variables while the attitude towards IPM practices in rice cultivation was the only dependent variable. Chi-square tests revealed that all variables except age, family size, farm size, supervision of crop production, annual income and peer relationship differed significantly with the attitude of the farmers. Stepwise multiple regression analysis indicated that aspiration alone contributed more than three-fifths $(65.10 \%)$ of the total variation, whereas knowledge about pests, predators and risk orientation had also considerable contribution to the attitude towards IPM practices. Results of the path co-efficient analysis showed that aspiration, knowledge about pests and predators, risk orientation, mass extension contact and communication exposure had strong direct and indirect effects on the attitude of the farmers towards IPM practices in rice cultivation in the study area.
\end{abstract}

Key words: Contributing variables, farmers' attitude, IPM, rice cultivation, Barind.

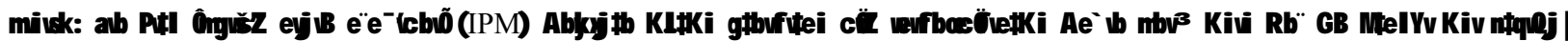

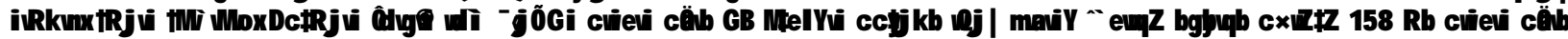

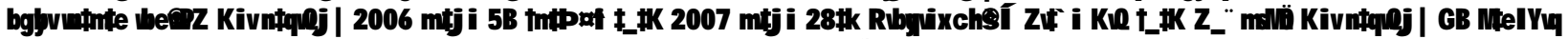

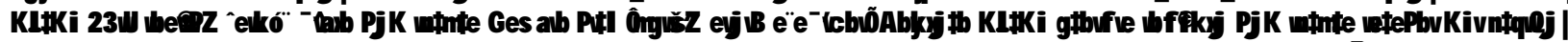

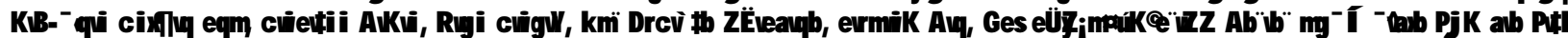

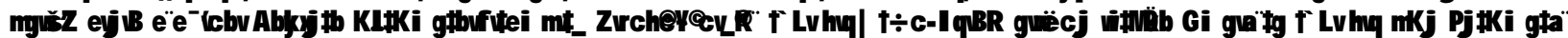

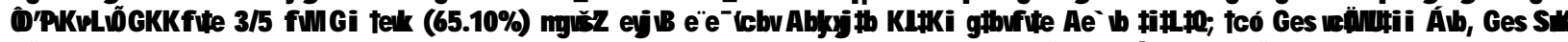

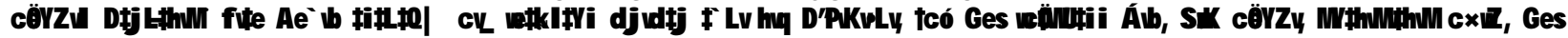

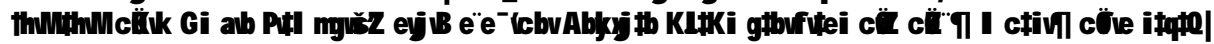

\section{Introduction}

The use of agrochemicals in agriculture is one of the available technologies which play a vital role in increasing productivity but its use is now considered hazardous for our ecosystem. The humid tropical climatic conditions of Bangladesh are conductive for the development of various pests of crops. Farmers control pests by using different kinds of pesticides in Bangladesh where 211 trade names have been registered (Islam 2005). Although pesticides provide temporary release from pest out break in the fields, indiscriminate use of pesticides not only creates serious environmental and human health hazards but also help in development of pest resistance to insecticides, destroys beneficial insects and imbalances the position between pests and their natural enemies, leading to the increase in the population of the target pest and even creating new pest problems. Pesticides may contaminate ground and surface water, thus harming downstream users of the chemicals leached to the water sources and have also been blamed for causing regular out breaks of epidemics in fishes (Ziauddin 1991). To avoid this consequence and to increase the crop production, a viable alternative is needed. In Bangladesh, Integrated Pest Management (IPM) activity was initiated through "FAO inter-country IPM in rice in South and South East Asia" in 1981 and the first phase continued up to 1987. Subsequently, IPM activities were undertaken by the Department of Agricultural Extension (DAE) through DAE-DANIDASPPS, DAE-UNDP/FAO and DAE-CAD Projects. DAE-DANIDA-SPPS was a five-year programme starting from July 1997 (Anon. 1999). Later on, Government of Bangladesh started IPM from January 2001 for high value crops in northwest Districts of Bangladesh (Anon. 2001). Reports suggest that IPM is one of the best alternative strategies for managing crop pests in many countries of the world (Anon. 2003).

Attitude is one of the important components of farmers' dealing that plays a vital role in their convert or overt behaviour. Some of the studies isolated the factors 
contributing and/or relating to the attitude of farmers (Karim et al. 1987, Kashem and Islam 1990, Pathak et al. 1993; Hamidi et al. 2004). Nevertheless, there is hardly any study in Bangladesh in this connection, especially in relation to farmers' attitude towards IPM practices in Barind area. Aforesaid facts call for an empirical study to determine the factors contributing to farmers' attitude in relation IPM practices for formulating an effective extension strategy. Keeping this in view, this study was conducted to examine the characteristics contributed to farmers' attitude towards IPM practices in rice cultivation.

\section{Materials and Methods}

The study was conducted in Godagari Upzila of Rajshahi District which is considered as Barind tract. Populations of the study area were the Farmers Field Schools (FFSs) farmers for rice cultivation. The total IPM trained up farmers through FFSs in this Upzila was 1050 from 42 FFSs, of which $15 \%$ were randomly selected as the representative sample of the study by using a Table of Random numbers (Kerlinger 1973). Data were collected from a sample of 158 farmers by using an interview schedule from 5 September, 2006 to 28 January, 2007.

Measurement of independent variables: The independent variables such as age $\left(\mathrm{X}_{1}\right)$, education $\left(\mathrm{X}_{2}\right)$, family size $\left(\mathrm{X}_{3}\right)$ and farm size $\left(\mathrm{X}_{12}\right)$ were measured by using the measuring units of year, year of schooling, number of members and hectare, respectively. Family education $\left(\mathrm{X}_{4}\right)$ score was determined by adding all individuals' education score of a family and divided by the effective family size (family members under 6 years were not considered). Training experience $\left(\mathrm{X}_{5}\right)$ was computed by the number of days of training that a farmer had received during last five years under different agricultural training programmes except the IPM training. Four point Likert type scale was used on 15 statements to measure supervision of crop production $\left(\mathrm{X}_{6}\right)$. The agricultural knowledge $\left(\mathrm{X}_{7}\right)$, knowledge about environmental pollution $\left(\mathrm{X}_{8}\right)$, knowledge about pests and predators in rice $\left(\mathrm{X}_{9}\right)$ and knowledge in IPM $\left(\mathrm{X}_{10}\right)$ of the respondents were calculated by asking relevant questions. The family labour force $\left(\mathrm{X}_{11}\right)$ was computed by assigning scores for the members of the family able to perform agricultural work. The annual income in Taka $\left(\mathrm{X}_{13}\right)$ was measured on the basis of total earnings by all the members of the family. Ownership of the agricultural implements $\left(\mathrm{X}_{15}\right)$ was calculated by the number of different agricultural implements and their corresponding scores. For measuring socio-economic status of the farmers $\left(\mathrm{X}_{14}\right)$, scores on self education, family education, farm size, annual income, formal group affiliation, types of house owned, availability of latrine, source of drinking water, ownership of agricultural implements and material possessions were summed up. The scores on the above ten items were added together to compute the socio-economic status of an individual farmer. Cosmopoliteness $\left(\mathrm{X}_{17}\right)$ of a farmer was measured by computing a cosmopoliteness score on the basis of his frequency of visits to six different places outside his own social system. A five point rating scale ranging from 'frequently' to 'not at all' was used to measure extension contact of the respondent. Communication exposure score $\left(\mathrm{X}_{18}\right)$ \{individual ${ }_{18(\mathrm{i})}$, group $_{18 \text { (ii) }}$ and $\left.\operatorname{mass}_{18(\mathrm{iii})}\right\}$ of the respondents was computed by summing the obtained scores against each of the 21 selected communication media (individual, group and mass) based on the extent of contact as ascertained from their responses. Formal group affiliation $\left(\mathrm{X}_{16}\right)$ of the respondents was measured on the basis of two dimensions viz. nature of involvement and number of organizations in which the respondents were involved. Peer relationship $\left(\mathrm{X}_{19}\right)$ was measured according to the number of day-contacts made by the respondent with five selected peers in a week. Risk orientation $\left(\mathrm{X}_{20}\right)$ and aspiration $\left(\mathrm{X}_{21}\right)$ were measured by using five point Likert type scale on 14 statements (7 positive and 7 negative).

Measurement of dependent variable: Farmers' attitude towards IPM practices in rice cultivation was the only dependent variable of the study. This was measured by using five point Likert type scale on 14 statements, which were selected by judges' rating, item analysis, validity and reliability test. A respondent was asked to indicate his/her extent of agreement or disagreement with each of the statements by strongly agreeing, agreeing undecidedly, disagreeing and strongly disagreeing. Scores assigned to these responses were 4, $3,2,1$ and 0 , respectively for positive statements and reverse scoring for the negative statements. Thus, the attitude scores of the respondents were determined by adding up the scores for responses against all 14 statements, varying between 0 and 56 .

Statistical analyses: Chi-square $\left(\chi^{2}\right)$ was computed to explore the relationship between the selected characteristics of the farmers and their attitude towards 
IPM practices in rice cultivation. In order to find out the contribution of independent variables to farmers' attitude towards IPM practices, step-wise multiple regression analysis was computed (Dropper and Smith 1981), which avoided the problems of multi-colinearity. Of 24 selected variables, only five $\left(\mathrm{X}_{21}, \mathrm{X}_{9}, \mathrm{X}_{20}, \mathrm{X}_{18 \text { (iii) }}\right.$ and $\mathrm{X}_{18}$ ) that had significant relationship with the dependent variable were kept for the analysis. In addition, path coefficient analysis (Sasmal and Chakraborti 1978) was computed to measure the direct and indirect effects of selected characteristics of the farmers to their attitude towards IPM practices. Since path co-efficient analysis is superior to multiple regression analysis because it is free from effects of measuring unit of variables (Li (1954), it also permitted the separation of the correlation co-efficient into components of direct and indirect effects (Dewey and Lu 1959).

Table 1. Results showing attitude towards IPM practices and the selected characteristics of respondent farmers

\begin{tabular}{|c|c|c|c|c|}
\hline \multirow[t]{2}{*}{ Dependent variable } & \multicolumn{2}{|r|}{ Independent variables } & \multirow[b]{2}{*}{$\chi^{2}$ values } & \multirow[b]{2}{*}{ df } \\
\hline & Code & Variable names & & \\
\hline \multirow{24}{*}{$\begin{array}{l}\text { Attitude towards IPM } \\
\text { practices }\end{array}$} & $\mathrm{X}_{1}$ & Age & $6.334 \mathrm{~ns}$ & 4 \\
\hline & $\mathrm{X}_{2}$ & Education & $39.011 * * *$ & 6 \\
\hline & $\mathrm{X}_{3}$ & Family size & $3.643 \mathrm{~ns}$ & 4 \\
\hline & $\mathrm{X}_{4}$ & Family education & $25.322 * * *$ & 4 \\
\hline & $\mathrm{X}_{5}$ & Training experience & $17.177 * *$ & 6 \\
\hline & $\mathrm{X}_{6}$ & Supervision of crop production & $9.267 \mathrm{~ns}$ & 4 \\
\hline & $\mathrm{X}_{7}$ & Apicultural knowledge & $35.638 * * *$ & 4 \\
\hline & $\mathrm{X}_{8}$ & Knowledge about environmental pollution & $21.977 * * *$ & 4 \\
\hline & $\mathrm{X}_{9}$ & Knowledge about pests and predators of rice & $67.764 * * *$ & 4 \\
\hline & $\mathrm{X}_{10}$ & Knowledge in IPM & $21.972 * * *$ & 4 \\
\hline & $\mathrm{X}_{11}$ & Family labour force & $21.566^{* *}$ & 6 \\
\hline & $\mathrm{X}_{12}$ & Farm size & $5.028 \mathrm{~ns}$ & 4 \\
\hline & $\mathrm{X}_{13}$ & Annual income & $4.619 \mathrm{~ns}$ & 4 \\
\hline & $\mathrm{X}_{14}$ & Socio-economic status & $20.688^{* * *}$ & 4 \\
\hline & $\mathrm{X}_{15}$ & Ownership of agricultural implements & $144.888^{* * *}$ & 4 \\
\hline & $\mathrm{X}_{16}$ & Formal group affiliation & $24.218^{* * *}$ & 6 \\
\hline & $\mathrm{X}_{17}$ & Cosmopoliteness & $125.845 * * *$ & 4 \\
\hline & $\mathrm{X}_{18}$ & Communication exposure & $25.387 * * *$ & 4 \\
\hline & $\mathrm{X}_{18(\mathrm{i})}$ & Individual extension contact & $10.768^{*}$ & 4 \\
\hline & $\mathrm{X}_{18(\mathrm{ii})}$ & Group extension contact & $51.856^{* * *}$ & 6 \\
\hline & $\mathrm{X}_{18 \text { (iii) }}$ & Mass extension contact & $38.318 * * *$ & 4 \\
\hline & $\mathrm{X}_{19}$ & Peer relationship & $5.534 \mathrm{~ns}$ & 4 \\
\hline & $\mathrm{X}_{20}$ & Risk orientation & $69.411 * * *$ & 4 \\
\hline & $\mathrm{X}_{21}$ & Aspiration & $85.611 * * *$ & 4 \\
\hline
\end{tabular}

ns $=$ Not significant, $*=\mathrm{P}<0.05 ; * *=\mathrm{P}<0.01 ; * * *=\mathrm{P}<0.001 ; \mathrm{df}=$ degrees of freedom.

Table 2. Summery of step-wise multiple regression analysis showing the contributions of five variables to the attitude of the respondent farmers

\begin{tabular}{|c|l|c|c|c|c|c|}
\hline $\begin{array}{l}\text { Step } \\
\text { No. }\end{array}$ & Variables entered & $\mathrm{R}$ & $\mathrm{R}^{2}$ & Adjusted $\mathrm{R}^{2}$ & $\begin{array}{c}\text { Increase in } \\
\mathrm{R}^{2}\end{array}$ & $\begin{array}{c}\text { Variance } \\
\text { explained (\%) }\end{array}$ \\
\hline 1 & $\mathrm{X}_{21}$ Aspiration & 0.808 & 0.653 & 0.651 & 0.651 & 65.10 \\
\hline 2 & $\mathrm{X}_{9}$ knowledge about pests and predators of rice & 0.834 & 0.695 & 0.691 & 0.040 & 4.00 \\
\hline 3 & $\mathrm{X}_{20}$ Risk orientation & 0.847 & 0.717 & 0.711 & 0.020 & 2.00 \\
\hline 4 & $\mathrm{X}_{18 \text { (iii) }}$ Mass extension contact & 0.852 & 0.726 & 0.719 & 0.008 & 0.80 \\
\hline 5 & $\mathrm{X}_{18}$ Communication exposure & 0.857 & 0.734 & 0.725 & 0.006 & 0.60 \\
\hline
\end{tabular}


Table 3. Path co-efficient showing the direct and indirect effects of selected independent variables on the farmers' attitude towards IPM practices

\begin{tabular}{|c|c|c|c|c|c|}
\hline Independent variables & $\begin{array}{l}\text { Standardized } \\
\text { co-efficient }\end{array}$ & $\begin{array}{l}\text { Direct } \\
\text { effect }\end{array}$ & $\begin{array}{c}\text { Indirect } \\
\text { effect }\end{array}$ & \multicolumn{2}{|c|}{ Variables through which indirect effects are channeled } \\
\hline \multirow{4}{*}{$\mathrm{X}_{21}$ Aspiration } & \multirow{4}{*}{0.541} & \multirow{4}{*}{0.541} & \multirow{4}{*}{0.266} & 0.090 & Knowledge about pests and predators of rice \\
\hline & & & & 0.143 & Risk orientation \\
\hline & & & & 0.117 & Mass extension contact \\
\hline & & & & -0.084 & Communication exposure \\
\hline \multirow{4}{*}{$\begin{array}{l}\mathrm{X}_{9} \text { Knowledge about pests } \\
\text { and predators in rice }\end{array}$} & \multirow{4}{*}{0.178} & \multirow{4}{*}{0.178} & \multirow{4}{*}{0.409} & 0.275 & Aspiration \\
\hline & & & & 0.091 & Risk orientation \\
\hline & & & & 0.135 & Mass extension contact \\
\hline & & & & -0.092 & Communication exposure \\
\hline \multirow{4}{*}{$\mathrm{X}_{20}$ Risk orientation } & \multirow{4}{*}{0.186} & \multirow{4}{*}{0.186} & \multirow{4}{*}{0.550} & 0.416 & Aspiration \\
\hline & & & & 0.087 & Knowledge about pests and predators of rice \\
\hline & & & & 0.136 & Mass extension contact \\
\hline & & & & -0.089 & Communication exposure \\
\hline \multirow{4}{*}{$\begin{array}{c}\mathrm{X}_{18(\mathrm{iii})} \text { Mass extension } \\
\text { contact }\end{array}$} & \multirow{4}{*}{0.262} & \multirow{4}{*}{0.262} & \multirow{4}{*}{0.279} & 0.242 & Aspiration \\
\hline & & & & 0.092 & Knowledge about pests and predators of rice \\
\hline & & & & 0.096 & Risk orientation \\
\hline & & & & -0.151 & Communication exposure \\
\hline \multirow{4}{*}{$\begin{array}{l}\mathrm{X}_{18} \text { Communication } \\
\text { exposure }\end{array}$} & \multirow{4}{*}{-0.176} & \multirow{4}{*}{-0.176} & \multirow{4}{*}{0.671} & 0.259 & Aspiration \\
\hline & & & & 0.093 & Knowledge about pests and predators of rice \\
\hline & & & & 0.094 & Risk orientation \\
\hline & & & & 0.225 & Mass extension contact \\
\hline
\end{tabular}

\section{Results and Discussion}

Relationship between attitude and selected characteristics of farmers: Results shown in Table 1 demonstrate that apart from age $\left(\mathrm{X}_{1}\right)$, family size $\left(\mathrm{X}_{3}\right)$, supervision of crop production $\left(\mathrm{X}_{6}\right)$, farm size $\left(\mathrm{X}_{12}\right)$, annual income $\left(X_{13}\right)$ and peer relationship $\left(X_{19}\right)$, all other characteristics of the respondents correlated significantly with their attitude towards IPM practices.

Contribution of selected independent variables to the farmers' attitude: Data presented in Table 2 indicate that only five independent variables were important and these explained $72.50 \%$ of the total variations in predicting the farmers' behaviour. Of them, aspiration $\left(\mathrm{X}_{21}\right)$ alone explained $65.10 \%$, because it played the most vital role in the whole process.

Direct and indirect effects of selected characteristics on farmers' attitude towards IPM practices: Data furnished in Table 3 suggest that aspiration had the highest positive direct effect $(0.541)$ on the farmers' attitude towards IPM practices in rice cultivation, followed by knowledge about pests and predators in rice (0.178). Risk orientation and mass extension contact had also positive and substantial direct effects $(0.186$ and 0.262$)$. The indirect effect was mostly channeled through other variables such as communication exposure that had a negative direct effect $(-0.176)$. It also had the highest total indirect effect $(0.671)$, whereas aspiration had the lowest (0.266).

A highly positive and direct substantial effect of aspiration in rice farmers may be explained as follows. The farmers of FFSs are usually marginal and small farmers that live on subsistence. It is quite important and logical that these farmers usually aspire more than the big and large farmers in respect of the increase production, income, standard of living and life style compared to the past decades. In this age, aspiration urges an individual towards prosperity and development. Hence, aspiration of the respondents 
played a vital role in predicting their attitude towards IPM in rice cultivation. It has been observed from many studies that higher level of aspiration of the farmers is related to the higher level of adoption of agricultural technologies. Hamidi et al. (2004) also found in their study on adoption of IPM practices in rice cultivation by the farmers that aspiration alone explained $67.7 \%$ of the variation, because it played a most vital role in the process.

\section{Conclusion}

All characteristics of the respondent farmers except age $\left(\mathrm{X}_{1}\right)$, family size $\left(\mathrm{X}_{3}\right)$, supervision of crop production $\left(\mathrm{X}_{6}\right)$, farm size $\left(\mathrm{X}_{12}\right)$, annual income $\left(\mathrm{X}_{13}\right)$ and peer relationship $\left(\mathrm{X}_{19}\right)$ correlated significantly with their attitude towards IPM practices in rice cultivation in Godagari, Rajshahi. Five such variables as aspiration $\left(\mathrm{X}_{21}\right)$, knowledge about pests and predators $\left(\mathrm{X}_{9}\right)$, risk orientation $\left(\mathrm{X}_{20}\right)$, mass extension contact $\left(\mathrm{X}_{18(\mathrm{iii})}\right)$ and communication exposure $\left(\mathrm{X}_{18}\right)$ were important as they explained $72.50 \%$ of the total variations in predicting the farmers' attitude. Of them, aspiration alone explained $65.10 \%$ and it had the highest positive direct effect $(0.541)$ and the lowest indirect effect $(0.266)$ on the farmers' attitude towards IPM practices, suggesting its vital role in the whole process. In addition, mass extension contact $(0.262)$, risk orientation $(0.186)$, and knowledge about pests and predators in rice $(0.178)$ had direct effects, while the indirect effect was mostly channeled through other variables such as communication exposure (-0.176), which had the highest indirect effect (0.671).

\section{References}

Anonymous, 1999. DAE-DANIDA Strengthening Plant Protection Services Project and Overview, DAEDANIDA, Khamarbari, Dhaka, Bangladesh.

Anonymous, 2001. A Leaflet of Northwest Crop Diversification Project, Project Management Unit, Department of Agricultural Extension, Khamarbari, Dhaka, Bangladesh.
Anonymous, 2003. Professors' Current Affairs Album. Professors' Publication, Dhaka, Bangladesh.

Dewey DP \& Lu KH. 1959. A correlation and path coefficient analysis of components of crested wheat grass seed production. J. Agron. 51: 515-518.

Dropper NK \& Smith H. 1981. Applied Regression Analysis. John Wiley and Sons Inc., New York, USA.

Hamidi MA, Kashem MA, Karim ASMZ and Islam MM. 2004. Adopting Integrated Pest Management practices in rice cultivation by farmers. Bangladesh J. Ext. Edu. 16(2): 1-8.

Islam MA. 2005. Farmers' Knowledge and Practices in Using IPM for Crop Production. Unpubl. M. Sc. Thesis, Department of Agricultural Extension Education, Bangladesh Agricultural University, Mymensingh.

Karim ASMZ, Hossain MA \& Shamsuzzoha ANM. 1987. Farmers' economic characteristics affecting their attitude towards use of urea in jute cultivation. Bangladesh J. Ext. Edu. 2(1): 67-75.

Kashem MA \& Islam M. 1990. Comparative analysis of knowledge, attitude and adoption of agricultural practices between the contact and non-contact farmers under T\&V system. Bangladesh J. Ext. Edu. 5(1\&2): 1-7.

Kerlinger FN. 1973. Foundations of Behavioural Research (2nd edn). Holt, Rinehart and Winston, Inc., New York, USA.

Li CC. 1954. Population Genetics. The University of Chicago Press, Chicago, USA.

Pathak S, Majumdar AK \& Sasmal BC. 1993. Influence of receivers' background on his attitude. Media Asia 20(2): 109-115.

Sasmal BC \& Chakrabarty... 1978. Correlation and path coefficient analysis of yield component in Mesta (Hibiscus cannabinus L.). Indian J. Heredity 10(2): 19-26.

Ziauddin AA. 1991. Nature, Environment and Danger to Civilization. Asian Central Forum on Development (ACFORD).

Manuscript received on 14 March 2010 and revised on 29 October 2010. 